\title{
The Robot of Prague
}

Ivan Margolius

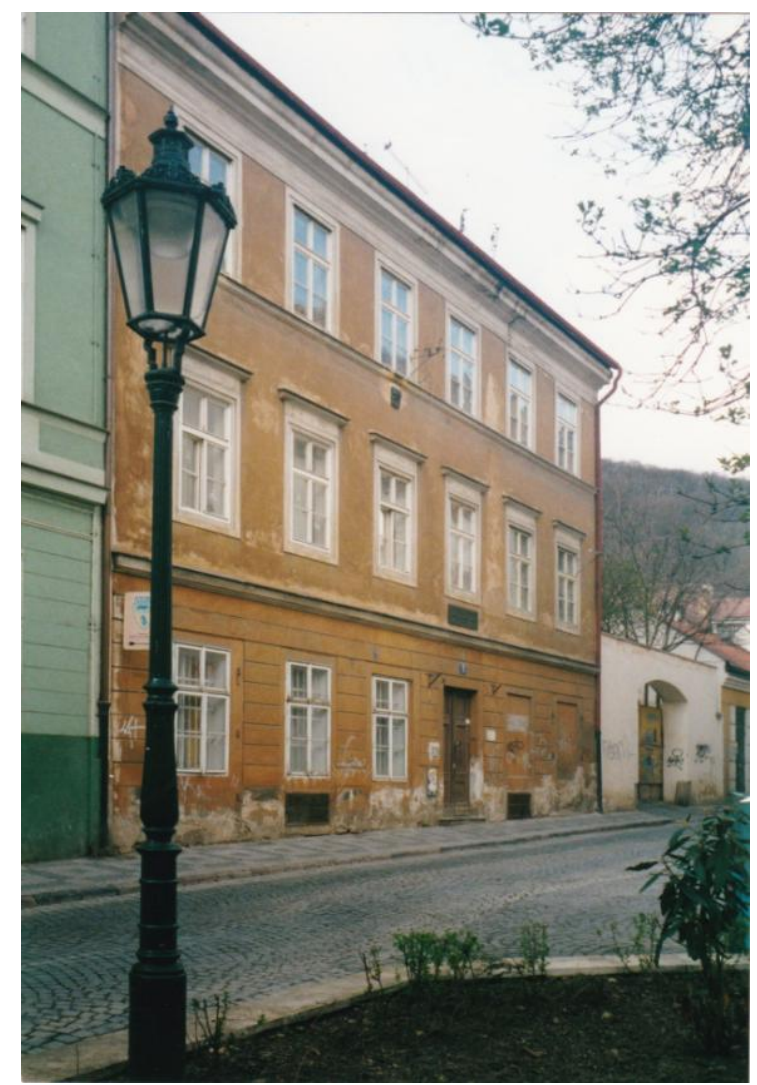

Whenever in Prague my first steps lead me to Říční Street, a quiet backwater in the Malá Strana quarter by the Vltava river, seen above as it appeared in 2003. Always, when I stand in front of number 11, I am amazed at the lack of tourists who flock to the city yearly to satisfy their cultural and travel cravings. Why do they miss the most important spot in Prague if not the whole world? Surely this is the centre of the universe.

An ordinary old, plain three-storey apartment house, half-way up a narrow cobbled street with a gateway into a yard at the rear: what is the fuss about, you ask? If you visit at present there is a clue in a bronze plaque fixed to the front façade just below the run of first-floor windows: $V$ tomto domé žili a tvorili bratrú Josef a Karel Capkové v letech 1907 1925' (Brothers Josef and Karel Čapek lived and worked in this house between 1907 and 1925).

Nowadays the world public is aware of Franz Kafka, Jaroslav Hašek and more recently Milan Kundera and Josef Škvorecký as authors who have originated from the Czech lands, while both Čapeks are now nearly forgotten. However, before the Second World War it was the anglophile Karel Čapek who was the best known. In the 1930s Karel became the foremost candidate for the Nobel Prize 
for Literature mainly for his plays R.U.R., The Makropulos Affair (turned into an opera by Leoš Janáček) and novel $W$ ar with the Newts, but he never received it. Čapek visited Britain in 1924 and made friends with G. B. Shaw, H. G. Wells and G. K. Chesterton and became an honorary member of the London PEN Club. Čapek also admired T. G. Masaryk and published Conversations with T. G. Masaryk. Karel's brother Josef was an acclaimed painter, graphic artist, writer and poet.

On August 6th, 1907 Karel Čapek (1890-1938) and Josef Čapek (1887-1945) moved to Říční 532/11 from Úpice, a small town under the Krkonoše Mountains in northern Bohemia where their father Dr Antonín Čapek (1855-1929) had his own house. The Prague flat was found by Božena (1866-1924) their mother, after Antonín had to abandon his Úpice medical practice due to illness.

The Ríćní house had six windows in the upper storeys with a yellow-painted façade. Josef had the larger corner room, where he had his easel, which had one window looking into the yard, and two street windows. After his marriage in 1919, Josefs and his wife Jarmila's bedroom was in the middle and the shared living room with two street windows was at the end. The kitchen next to Karel's room faced the yard through the glazed, access walkway. Karel's room was furnished with simple furniture from the previous century. It was a narrow room with one window facing the yard and his writing desk underneath. His brother's paintings hung on the walls.

Karel had just finished the play The Outlaw (Loupežník), submitting the manuscript to his publisher Otakar Štorch-Marien. At the same time,

11 Řicni Street, Malá Strana, Prague: the Capeks' apartment plan at first floor level. The word 'robot' was first pronounced in Josef Capek's studio (pracovna), top left

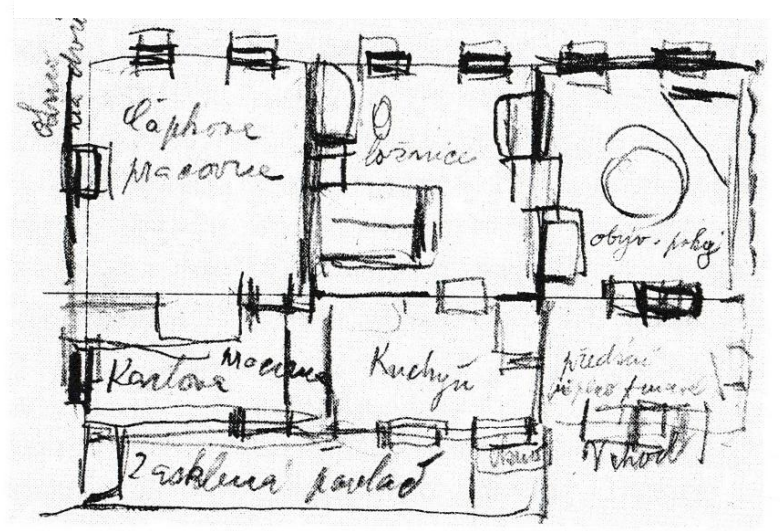

Karel started on his new project. Karel was preoccupied with the contemporary difficult conditions of the factory workers and the hard-line attitude of their bosses ever since writing the story System together with his brother Josef, published first in the weekly Národni obzor on October 3rd, 1908. The memory of the Úpice textile workers on strike whom he had witnessed, seeing their march through the town, and the knowledge of newly introduced mass production and scientific management methods of manufacturing became his inspiration. In System the Čapek brothers described the action of a greedy factory owner who tried to employ workers devoid of human needs, ideas and emotions, purely to be used as automata and working machines to achieve the most efficient manufacturing means. However, after one worker had a visit by a pretty woman in his accommodation cell, his passions were aroused and having affected his fellows, the workers revolted, killed the owner's family and set fire to the factory buildings.

A further impetus came, as Karel explained in an article in London's Evening Standard in 1924. One day he had to take a tram from Prague's suburbs to the city centre. The tram was uncomfortably overcrowded. He was astounded how modern living situations made people unconcerned about their normally accustomed living comforts. People were pressed together inside, even spilling outside on to the tram steps, appearing not like herded sheep, but like machines. He started to think about people not as individuals but as machines and during the journey thought about an expression which would describe a human being only able to work but not able to reason.

With that in mind, Karel began to write a drama about the manufacture of artificial people from man-made organic material who would free humans of work and drudgery, but finally due to overproduction those labouri would lead humankind to destruction and annihilation. He chose names of characters that carried symbolic meaning: Domin from dominus for the general manager of Rossum's (derived from the Czech word rozum: mind, intelligence, sense, reason), Alquist, head of the works department, from the Latin aliquis, Fabry, engineer general from fabrika (factory), Busman, general commercial manager from 'businessman', Dr Gall, head of the physiological and experimental department from Galen and names from antiquity for the artificial beings such as Marius and Sulla. 

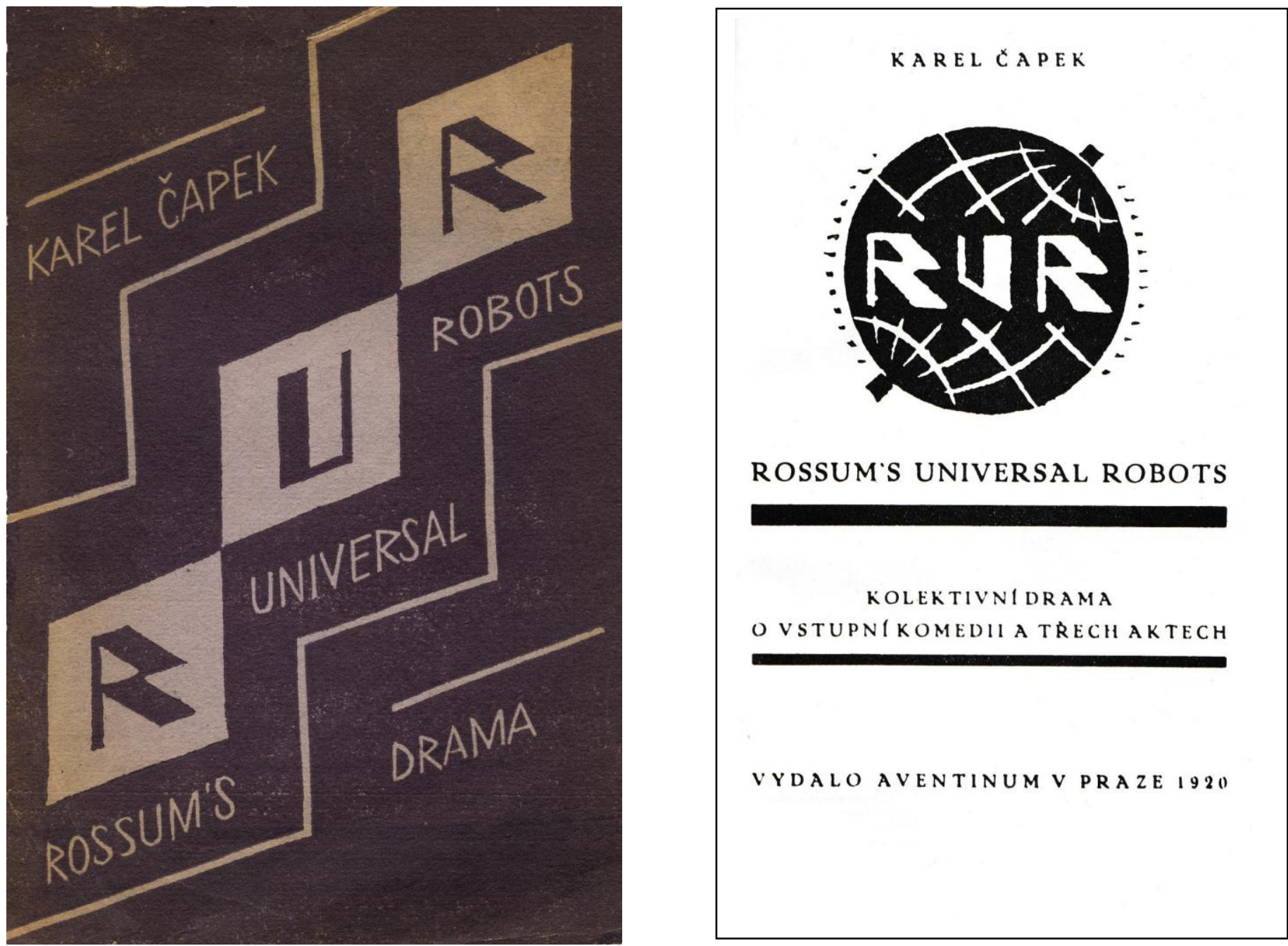

Left, the cover of the first edition of R.U.R., November 1920; right, the title page of the first edition

For what to call the artificial workers he turned for help to his brother Josef. Karel described the occasion some 23 years later in the newspaper Lidové noviny of December 24th, 1933, in Kulturni kronika column, on page 12:

'The author of the play R.U.R. did not, in fact, invent that word; he merely ushered it into existence. It was like this: the idea for the play came to said author in a single, unguarded moment. And while it was still fresh he rushed immediately to his brother Josef, the painter, who stood before an easel, vigorously painting at a canvas.

"Listen, Josef," the author began, "I think I have an idea for a play."

"What kind?" the painter muttered (he really did mutter, because at the moment he was holding a brush in his mouth). The author told him as concisely as he could.

"Then write it," the painter said, without taking the brush from his mouth or stopping to work on the canvas. His indifference was almost insulting.

"But," the author said, "I don't know what to call those artificial workers. I could call them labouri, but that strikes me as a bit literal."

"Then call them robots," the painter muttered, brush in mouth, and carried on painting.'

In the summer of 1920 Karel decided to fine-tune the play at his parents' place in Trenčianské Teplice and to have complete peace rented an attic room in the next door house. Despite the tropical heat of that summer, after a week of intensive work, he completed the play. By the beginning of August 1920 he was back in Prague. In November the play was published by Aventinum in a large run of 2000 copies with the cover in purple-brown designed by Josef, hardly four weeks after signing the contract.

The first premiere was at Klicperovo divadlo in Hradec Králové by the local amateur players on January 2nd and 3rd, 1921 followed by the National Theatre's official production in Prague on 


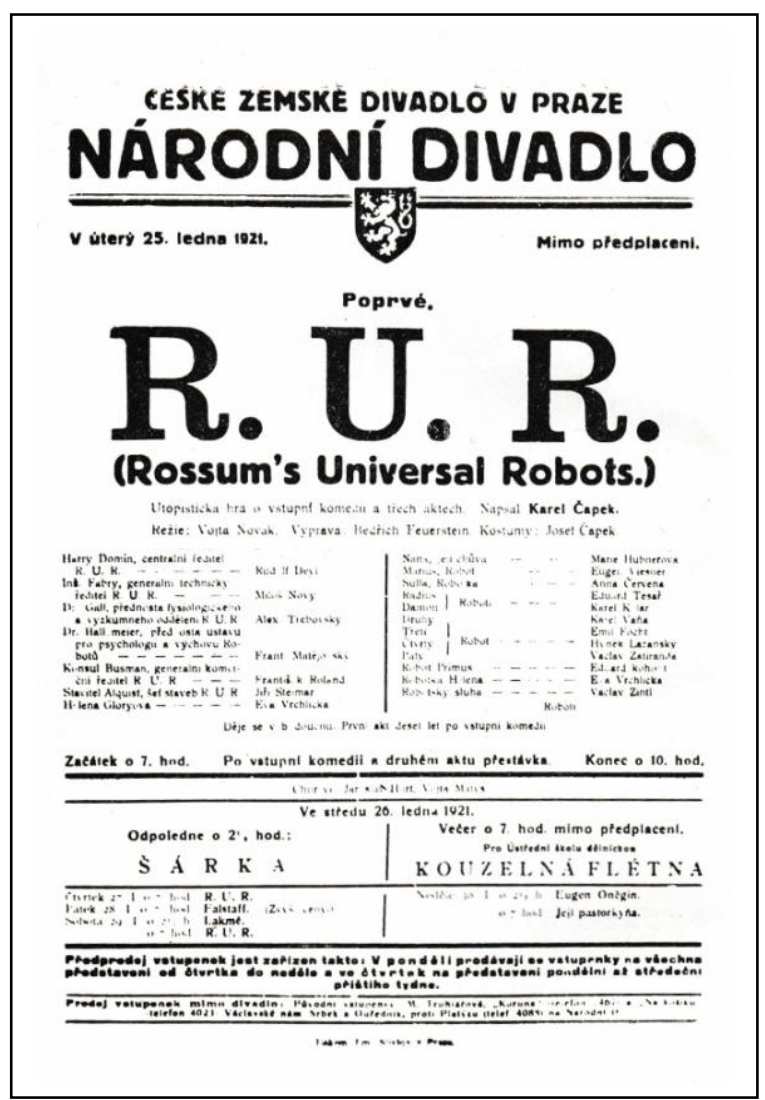

National Theatre, Prague, programme for the premiere, January 25th, 1921.

January 25th, 1921 with the stage set designed by architect Bedřich Feuerstein and directed by Vojta Novák, with costumes by Josef Čapek. The play, according to a review in Lidové noviny on January 27 th, had a thunderous reception and many stage calls were requested of the author at the end of the show.

The play describes the activities of Rossum's Universal Robots company that makes artificial people from synthetic, organic matter. These beings are not mechanical creatures, they may be mistaken for humans and can think for themselves. Initially they seem happy to work for humans, but that changes with time, and at the end a hostile robot revolt points to the extinction of the human race, perhaps to be saved by a male robot and a female robot acting as Adam and Eve. Karel wrote that all the characters in the play had the right to exist, this circumstance must be carried through even if it ends in tragic consequences, otherwise greatness would not be attained. After the reality of conflicts life carries on, if there is no faith in life it is not worth to continue living.' In my works nothing ends in death. I do not mean that life is a solution and purpose of everything, but is an eternal culmination, continuation and reconciliation of everything.'
Since then, and almost immediately, the robot word (other Czech contributions to the English dictionary are pistol, polka) explained as deriving from the Czech word robota ('hard work') by the quick-witted Josef, has become a universal expression in most languages for artificialintelligence machines invented by humans to help in their endeavours. Artificial human-like beings or intelligent machines have been thought of and written about before Čapek, such as the Golem, Frankenstein, the Steam Man, Tik-Tok, etc., but only now there was a word that described aptly the 'new species'. This word, coming out in the first two decades of the twentieth century, joined other important discoveries and inventions as cornerstones of the rise of Modernism in the arts and sciences, such as X-rays, radiotelegraphy, radium, polonium, quantum theory, relativity theory, four-dimensional geometry, Cubism, aeroplane flight, etc. A new spirit was thought to have arrived, a spirit of the synthesis of new concepts, of a new human élan, of multiple views of reality, ambiguity of meaning as in Kafka's works, leading towards new humanity and a new kind of people with a burning desire for sunlight, clean air and clear thought, a new attitude to life. Čapek's robots were a pure example of modernity not just in the name but by being ambiguous between the real being and the artificial machine. It prompted and inspired contemporary artists, writers and architects to create novel ideas based on new thinking and not on an imitation of the past, as had happened before.

So do me a favour when next in Prague: please pay homage to the birth of the most famous Czech word in worldwide use in the place of its conception.

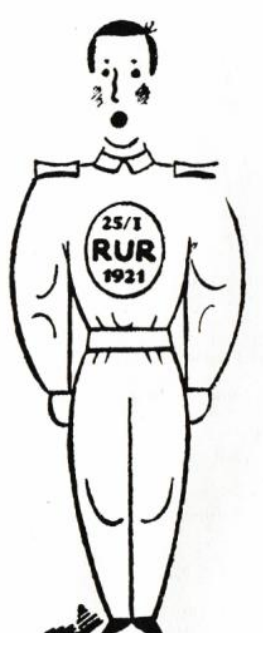

Caricature of Karel Capek from 1921 